\title{
Familial syndrome with panhypopituitarism, hypoplasia of the hypophysis, and poorly developed sella turcica
}

\author{
P. SIPPONEN,* S. SIMILÄ, Y. COLLAN, T. AUTERE, AND R. HERVA \\ From the Kainuu Central Hospital, Kajaani, the Department of Pathology, University of Helsinki, \\ and the Departments of Paediatrics and Pathology, University of Oulu, Finland
}

SUMMARY Two sisters who died at the ages of 2.5 years and 5 weeks are described. Both showed signs of panhypopituitarism. At necropsy, no hypophysis could be found in the first child and a rudimentary and partly ectopic hypophysis was found in the other. Both children had a flat, poorly developed sella turcica, and the sellar anomaly could be seen in skull $x$-rays. These patients represent a hereditary syndrome characterised by neonatal panhypopituitarism, hypoplasia of the pituitary gland, and flat sella turcica.

Congenital hypopituitarism may result from various anomalies of the hypophysis-such as absence, hypoplasia, or ectopia of the hypophysis. It also occurs in anencephaly and holoprosencephaly and may be connected with anomalies in the proximity of the hypophysis (e.g. cleft lip and palate with pituitary insufficiency, septo-optic dysplasia, and pituitary dwarfism) (Rimoin and Schimke, 1971). Patients with aplasia, hypoplasia, or ectopia of the hypophysis show signs of hypopituitarism soon after delivery, with persistent hypoglycaemia as the most conspicuous clinical feature. Hypoglycaemia usually leads to convulsions and brain damage (Steiner and Lawrence, 1953; Ehrlich, 1957; Aimone and Campagnoli, 1970; Moncrieff et al., 1972; Johnson et al., 1973). The sella turcica was normal in many of the cases with hypophyseal aplasia or hypoplasia (Steiner and Boggs, 1965) but there were reports of a small sella in some of these cases (Blizzard and Alberts, 1956; Dunn, 1966; Ferrier and Stone, 1969).

We report 2 sisters who died at ages 2.5 years and 5 weeks, both of whom showed clinical symptoms suggestive of panhypopituitarism. At necropsy the hypophysis was hypoplastic or absent and the sella turcica poorly developed and flat; sellar abnormality could be demonstrated radiologically. Findings suggest that hypoplasia of the hypophysis with a flat, poorly developed sella is an inherited clinical syndrome with characteristic radiological features.

Received 1 February 1978

* Present address: Pathology Department, Jorvi Hospital, Espoo, Finland

\section{Case reports}

The parents, both healthy, lived in an area known to contain genetic isolates but there was no known consanguinity. The mother suffered from hydramnios during both pregnancies and had had slight toxaemia and abnormal glucose tolerance tests during her second pregnancy.

Case 1. This baby girl born by caesarean section weighing $3990 \mathrm{~g}$ died at age $2 \cdot 5$ yeárs. She had only one umbilical artery. Her eyes were small and deeply set and the frontal bone was prominent, but otherwise the appearance was normal. She was jaundiced for 2 weeks after delivery. Soon after birth she developed severe hypoglycaemia which was treated with parenteral glucose infusions and cortisone. Hydrocortisone twice a week maintained normal blood glucose levels for a few months. This treatment was stopped at the age of one year and hypoglycaemic attacks reappeared 6 months later. She later developed epilepsy, probably secondary to brain damage caused by hypoglycaemia. Growth in weight and height was retarded. She suffered numerous infections-pneumonia and urinary tract infections several times and viral meningitis once. She died from heart failure and lung oedema after severe pneumonia.

Karyotype; bone age; and urinary amino-acids and urinary carbohydrate chromatography were all normal. Laboratory tests for thyroid function showed abnormally low values (T3 $65.6 \%$ and T4 $2.3 \mu \mathrm{g} / \mathrm{ml}(2.96 \mu \mathrm{mol} / \mathrm{l}))$, and replacement with 
thyroxine was begun at 2 years. The sella turcica was invisible in the $x$-ray taken immediately after delivery, but this was ascribed at the time to radiographic errors.

At necropsy no hypophysis could be found in the sella turcica or on the base of the brain, despite thorough study. The sella turcica was unusually flat, although the skull and brain were otherwise normal. The adrenals had normal cortical layers, a diameter of approximately $1 \mathrm{~cm}$ and a combined weight of $1 \mathrm{~g}$. The thyroid weighed $750 \mathrm{mg}$. The pancreas, and the number of islets of Langerhans appeared normal. The thymus was small, weighing $5 \mathrm{~g}$, and the thymic medulla was poorly developed and contained small Hassal's corpuscles in decreased numbers.

Case 2. This baby girl was delivered at the 39th week of pregnancy by caesarean section. The birthweight was $3600 \mathrm{~g}$, and the Apgar score 8 at one minute and 10 at 5 minutes. She looked like her sister, with small, deeply set eyes, low nasal bridge, and prominent frontal bone. Severe hypoglycaemia and moderate hyperbilirubinaemia developed after birth Normal blood glucose level during the 2 first days could be maintained only with a continuous infusion of hypertonic glucose. Hyperbilirubinaemia was treated with phototherapy.

The child was lethargic and had a weak voice when crying. Nasogastric feeding was necessary. Panhypopituitarism was suspected and $x$-rays showed that the sella turcica was abnormally flat (Figure). Endocrine tests showed primary hypocortisolism, slight primary hypothyroidism, and probable deficiency of growth hormone (Table). The basal serum cortisol concentration was 0.03 $\mu \mathrm{mol} / \mathrm{l}(10.8 \mu \mathrm{g} / \mathrm{l})$, but increased to $0.19(68.8$ $\mu \mathrm{g} / \mathrm{l}) 2$ hours after injection of $250 \mu \mathrm{g}$ ACTH IM. The diurnal rhythm of serum ACTH concentration was 10,257 , and $157 \mathrm{ng} / \mathrm{l}$. Hydrocortisone $\left(20 \mathrm{mg} / \mathrm{m}^{2}\right.$ and thyroxine $(3 \mu \mathrm{g} / \mathrm{kg})$ treatment was started at the age of 25 days, but the child went downhill and died from cardiac arrest on the second day of treatment.

At necropsy the body weighed $4100 \mathrm{~g}$ with a crown to heel length of $52 \mathrm{~cm}$. Naked-eye, the base of the

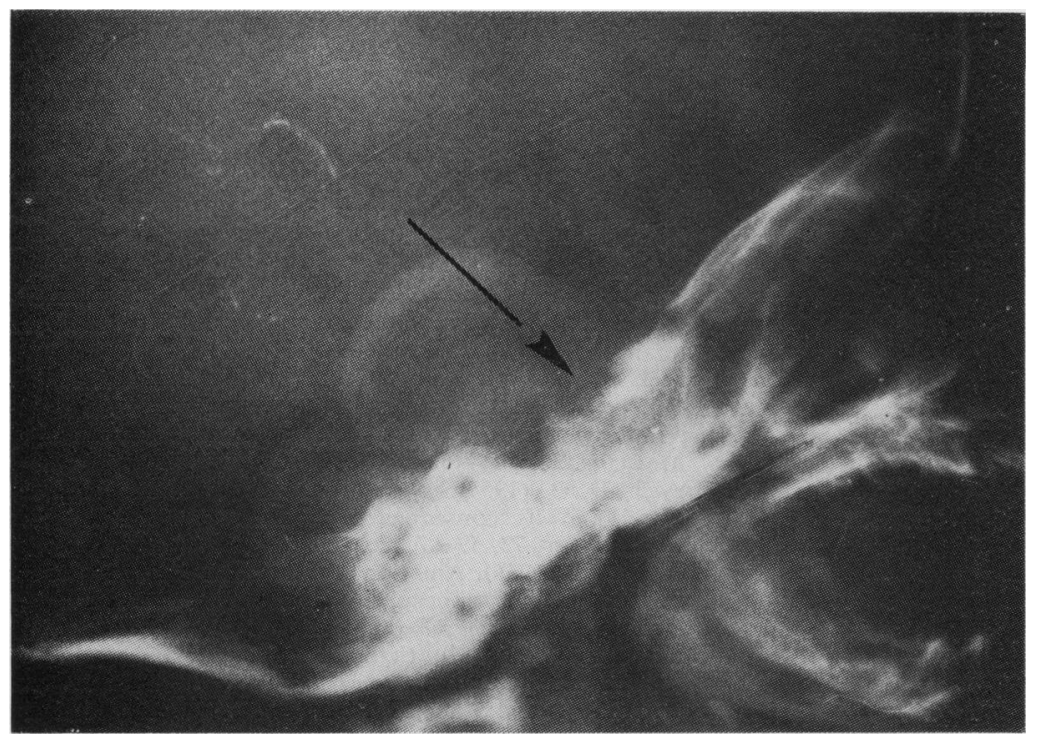

Figure Case 2. X-ray of sella turcica (arrow) showing flattening.

Table Case 2. Serum concentrations of TSH, T4 and T3 after intravenous TSH (100 $\mu \mathrm{g})$, and baseline values o, prolactin, $\mathrm{LH}, \mathrm{FSH}$, and growth hormone $(H G H)$

\begin{tabular}{|c|c|c|c|c|c|c|c|}
\hline $\begin{array}{l}\text { Time } \\
(\min )\end{array}$ & $\begin{array}{l}T S H \\
(U / l)\end{array}$ & $\begin{array}{l}\mathrm{T} 4 \\
(\mathrm{nmol} / \mathrm{l})\end{array}$ & $\begin{array}{l}\text { T3 } \\
(\mathrm{nmol} / \mathrm{l})\end{array}$ & $\begin{array}{l}\text { Prolactin } \\
(\mu g / l)\end{array}$ & $\begin{array}{l}\boldsymbol{L H} \\
(\boldsymbol{U} / I)\end{array}$ & $\begin{array}{l}F S H \\
(U / I)\end{array}$ & $\underset{(\mu g / l)}{H G H}$ \\
\hline $\begin{array}{r}0 \\
20 \\
60\end{array}$ & $\begin{array}{r}2 \cdot 7 \\
16 \cdot 3 \\
19 \cdot 2\end{array}$ & $\begin{array}{l}106 \\
102 \\
100\end{array}$ & $\begin{array}{l}1 \cdot 2 \\
1 \cdot 4 \\
1 \cdot 5\end{array}$ & $8 \cdot 2$ & $3 \cdot 8$ & 0.5 & 0.6 \\
\hline
\end{tabular}

Conversion: SI to traditional units-T4: $1 \mathrm{nmol} / 1 \approx 0.078 \mu \mathrm{g} / 100 \mathrm{ml} ; \mathrm{T} 3: 1 \mathrm{nmol} / 1 \approx 0.65 \mathrm{ng} / \mathrm{ml}$. 
skull was normal, except that there was no sella turcica and no hypophysis could be identified. The whole body of the sphenoid bone was fixed in $3 \%$ formaldehyde, decalcified, embedded in paraffin and cut in series, in which a miniature hypophyseal fossa with a diameter $2 \mathrm{~mm}$ could be seen containing adenohypophyseal cells. In addition, a pharyngeal pituitary with an epithelial extension towards the hypophyseal fossa was present in the roof of the nasopharynx. Both parts of the adenohypophysis contained the normal cell types but neurohypophyseal tissue could not be found.

The adrenals were hypoplastic with a total weight of $1 \mathrm{~g}$. The greatest diameter of the left adrenal was $6 \mathrm{~mm}$, and of the right $10 \mathrm{~mm}$. Histologically, both consisted of an adult-type cortical zone and a hypoplastic fetal zone. The thyroid gland was of normal shape with symmetrical lobes, but hypoplastic, weighing $1 \mathrm{~g}$. The gland was composed of follicles of varying sizes with a low cuboidal epithelium. A small nest of aberrant thymic tissue was seen in the thyroid gland. The ovaries were normal for age. Histologically, numerous oocytes and some cystic follicles were seen. The thymus weighed $10 \mathrm{~g}$ and was macroscopically and histologically normal. No histological abnormalities were found in other organs.

\section{Discussion}

The necropsy findings showed a severe hypophyseal anomaly in both of these sisters. A hypophysis could not be found in Case 1 who lived for 2.5 years. The fact that she lived this long might suggest that some hypophyseal tissue was present. Usually, patients with hypophyseal aplasia die soon after delivery, although there are some who have lived for years with intensive replacement therapy (Steiner and Boggs, 1965; Sadeghi-Nejad and Senior, 1974).

In addition to hypoplastic hypophysis, Case 2 showed clinical and laboratory evidence suggestive of polyendocrinopathy-primary hypocortisolism, slight primary hypothyroidism, and deficiency of HGH. Both patients suffered from severe hypoglycaemia and, in addition, atrophy of both thyroid and adrenal glands was revealed at necropsy.

Clinical findings have been uniform in cases showing hypoplasia of the hypophysis (Blizzard and Alberts, 1956; Mosier, 1956; Ehrlich, 1957; Ferrier and Stone, 1969; Johnson et al., 1973) or those in whom aplasia of the hypophysis was present (Brewer, 1957; Reid, 1960; Steiner and Boggs, 1965; Moncrieff et al., 1972; Sadeghi-Nejad and Senior, 1974). Our cases, however, had two additional prominent features. Firstly, hypophyseal hypoplasia was probably inherited and, secondly, both cases showed abnormal flattening of the sella turcica.

Three reports of hypoplasia or aplasia of the hypophysis showed a familial pattern (Mosier, 1956; Ferrier and Stone, 1969; Sadeghi-Nejad and Senior, 1974). Our cases fall into this group, although there was no previous history of similar cases in the family. This suggests an autosomal recessive type of inheritance, as in the cases described by Ferrier and Stone (1969).

Hypopituitarism which appears later in life and is symptomless during the neonatal period usually shows no changes in the sella turcica (Brasel et al., 1965). Such patients tend to have an isolated defect of one hypophyseal hormone only, often growth hormone deficiency (and dwarfism), and this condition also occasionally shows a recessive autosomal mode of inheritance (Trygstad and Seip, 1964; Rimoin et al., 1966; Seip et al., 1968; Rimoin and Schimke, 1971).

Although most of the cases with hypophyseal hypo- or aplasia show no changes in the sella turcica, some do have, as in our cases, a small sella turcica (Blizzard and Alberts, 1956; Dunn, 1966) or a small sella with a prominent dorsum sellae (Ferrier and Stone, 1969).

\section{References}

Aimone, V., and Campagnoli, C. (1970). Severe adrenal hypoplasia in a live-born normocephalic infant with neurohypophyseal aplasia. American Journal of Obstetrics and Gynecology, 107, 327-328.

Blizzard, R. M., and Alberts, M. (1956). Hypopituitarism, hypoadrenalism, and hypogonadism in the newborn infant. Jour nal of Pediatrics, 48, 782-792.

Brasel, A., Wright, J. C., Wilkins, L., and Blizzard, R. M. (1965). An evaluation of seventy-five patients with hypopituitarism beginning in childhood. American Journal of Medicine, 38, 484-498.

Brewer, D. B. (1957). Congenital absence of the pituitary gland and its consequences. Journal of Pathology and Bacteriology, 73, 59-67.

Dunn, J. M. (1966). Anterior pituitary and adrenal absence in a live-born normocephalic infant. American Journal of Obstetrics and Gynecology, 96, 893-894.

Ehrlich, R. M. (1957). Ectopic and hypoplastic pituitary with adrenal hypoplasia. Journal of Pediatrics, 51, 377-384.

Ferrier, P. A., and Stone, E. F., Jr (1969). Familial pituitary dwarfism associated with an abnormal sella turcica. Pediatrics, 43, 858-865.

Johnson, J. D., Hansen, R. C., Albritton, W. L., Werthemann, U., and Christiansen, R. O. (1973). Hypoplasia of the anterior pituitary and neonatal hypoglycemia. Journal of Pediatrics, 82, 634-641.

Moncrieff, M. W., Hill, D. S., Archer, J., and Arthur, L. J. H. (1972). Congenital absence of pituitary gland and adrenal hypoplasia. Archives of Disease in Childhood, 47, 136-137.

Mosier, H. D. (1956). Hypoplasia of the pituitary and adrenal cortex: report of occurrence in twin siblings and autopsy findings. Journal of Pediatrics, 48, 633-639. 
Reid, J. D. (1960). Congenital absence of the pituitary gland. Journal of Pediatrics, 56, 658-664.

Rimoin, D. L., Merimee, T. J., and McKusick, V. A. (1966). Growth-hormone deficiency in man: an isolated, recessively inherited defect. Science, 152, 1635-1637.

Rimoin, D. L., and Schimke, R. N. (1971). Genetic Disorders of the Endocrine Glands. Mosby: St Louis.

Sadeghi-Nejad, A.. and Senior, B. (1974). A Familial syndrome of isolated 'aplasia' of the anterior pituitary. Diagnostic studies and treatment in the neonatal period. Journal of Pediatrics, 84, 79-84.

Seip, M., van der Hagen, C. B., and Trygstad, O. (1968). Hereditary pituitary dwarfism with spontaneous puberty. Archives of Disease in Childhood, 43, 47-52.

Steiner, M. M., and Boggs, J. D. (1965). Absence of pituitary gland, hypothyroidism, hypoadrenalism and hypo- gonadism in a 17-year-old dwarf. Journal of Clinical Endocrinology, 25, 1591-1598.

Steiner, M. M., and Lawrence, G. (1953). Rare dwarfism with chronic hypoglycemia and convulsions. Observations with (1) ACTH and cortisone, (2) ACTH and thyroid. Journal of Clinical Endocrinology, 13, 283-299.

Trygstad, O., and Seip, M. (1964). Hereditary pituitary dwarfism treated with human growth hormone. Acta paediatrica Scandinavica, 53, 527-532.

Correspondence to Dr Yrjö Collan, University of Helsinki, Haartmanink 3, SF-00290 Helsinki 29, Finland. 